\title{
Ecotoxicity of hospital wastewaters and their impact on bacterial multi-drug resistance: a review
}

\author{
Ganamé Abasse OUEDRAOGO', Souleymane KONE ${ }^{1}$, Arouna OUEDRAOGO ${ }^{1}$, Henri Sidabéwindin \\ OUEDRAOGO ${ }^{1}$, Roukiétou TRAORE ${ }^{1}$, Hama CISSE ${ }^{1}$, Ismael Henri Nestor BASSOLE ${ }^{2}$, Yves TRAORE ${ }^{1}$ \\ and Aly SAVADOGO ${ }^{1 \star \otimes}$
}

${ }^{1}$ Laboratory of Applied Biochemistry and Immunology, University Joseph Ki-ZERBO, 03 BP 7021 Ouagadougou 03, Burkina Faso
${ }^{2}$ Laboratory of Epidemiology and Surveillance of Foodborne Diseases, University Joseph Ki-ZERBO, 03 BP 7021 Ouagadougou 03, Burkina Faso
Corresponding author's Email: alysavadogo@gmail.com; (DORCiD: https://orcid.org/o0oo-0002-909o-290X

\section{ABSTRACT}

Introduction. Hospitals use large varieties of substances for medical purposes such as in diagnostics, research, and upkeep of care materials. Diagnostic materials/substances, disinfectants, and excreted non-metabolized pharmaceuticals by patients, reach the wastewater. This form of elimination may generate risks for aquatic organisms, the emergence of antibiotic resistance, and human health problems. Aim. The aim of this study was to synthesize the contribution of liquid hospital effluents to the fragility of health in general and the emergence of bacterial resistance in particular. Methods. The data were collected from science's database using keywords. Results. The results showed that the heavy metal residues in these effluents and their bacterial selection mechanism reduce biodiversity, increase the vulnerability of urban and peri-urban populations, and promote the proliferation of multi-drug resistant bacteria. The threat is particularly worrying with the advent of resistance to the beta-lactams. Recommendation. Intervention strategies must be integrated and targeted at those primarily responsible for the management of hospital

Review Article

PII: S225199392100008-11

Rec. 20 June 2021

Rev. 19 July 2021

Acc. 25 July 2021

Keywords

Hospital liquid effluent,

Physico-chemical

parameter,

Bacterial resistance liquid effluents and the systems for handling these effluents.

\section{INTRODUCTION}

The large quantity of liquid effluents generated by hospital activities can contain many important micropollutants with various substances (drug residues, chemical reagents, antiseptics, detergents, etc.) and pathogenic agents [1-3]. These effluents, as well as conventional domestic wastewater, are usually discharged into urban networks without prior treatment $[4,5]$. The discharge of these effluents in the urban sewer networks or into the natural environment can generate risks for human health. These effluents represent also a significant contribution to the general contamination of the environment [6-9]. Chemical residues are toxic environmental pollutants and are the most highly bio-concentrated trace metals [8]. Their residues come from thermometers, gastric sound, drugs, hormones, etc., and can affect the lives of local fauna and flora. However, the residues of antibiotics in wastewater contribute significantly to the spread of multidrug-resistant bacteria in the environment [10]. This is because investigations have shown favorable correlations between the physicochemical parameters of wastewater and the dissemination and evolution of resistance genes [11-14]. Despite multiple awareness campaigns carried out by WHO and its partners through conferences, research and awareness campaigns, water hygiene, and its consequences remain very limited or even unknown [15-19]. Thus, in developing countries and particularly in Africa, the information on the hospital liquid effluent's characteristics is very scarce. To the best of our knowledge, only a few publications from Africa are available in the open literature. The aim of the present study is to present the physicochemical or microbiological characterization of hospital effluents and their risks to human health and the aquatic ecosystem. Specifically; (i): the evacuation in nature of these effluents loaded with disinfectants and detergent without adequate treatment; (ii): residues of pathogenic bacteria and antibiotic residues in these effluents; (iii): the presence of resistance genes in these effluents and their transfer mechanisms. 


\section{METHODS}

Relevant papers on the subject were searched using the Web of Science database. The keywords to search the database included "physicochemical of hospital's wastewater or microbial of hospital's wastewater", "hospital's wastewater and risks of hospital's wastewater for human health and risks of hospital's wastewater for the aquatic ecosystem", "ecotoxicity of mercury in hospital's wastewater", "antibacterial resistance and hospital wastewaters". The papers included in this review those published between the years 2002 and 2021. Papers dealing specifically with that on keywords have been included (Figure 1). This was done to identify recent trends in hospital wastewater physicochemical and their risks for human health and the aquatic ecosystem.

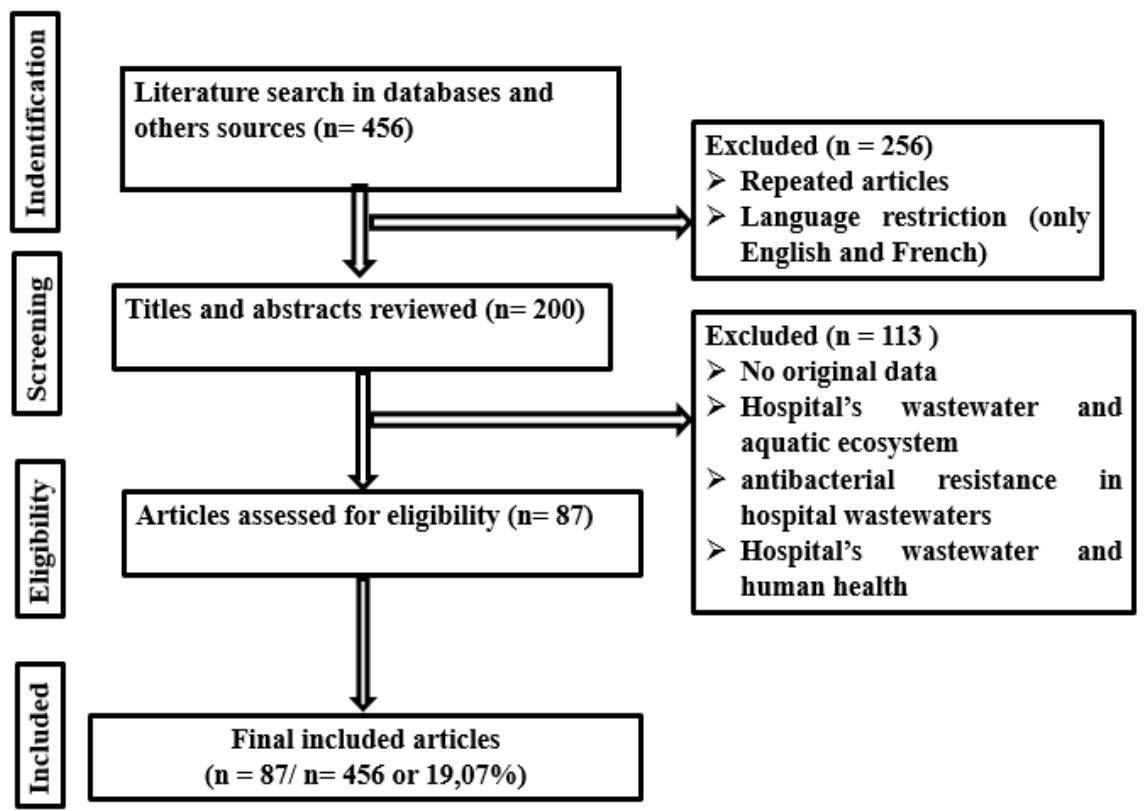

Figure 1. Procedure for selecting articles

\section{Risk assessment methods associated with hospital wastewaters}

Hospital wastewater could generate ecotoxicity and human or animal health problems [20]. These risks are due to non-compliance with microbial and physicochemical standards and the exposure of the local population to these effluents discharged into nature [1]. Figure 2 shows the different risk assessment points associated with hospital wastewaters effluents discharged into nature.

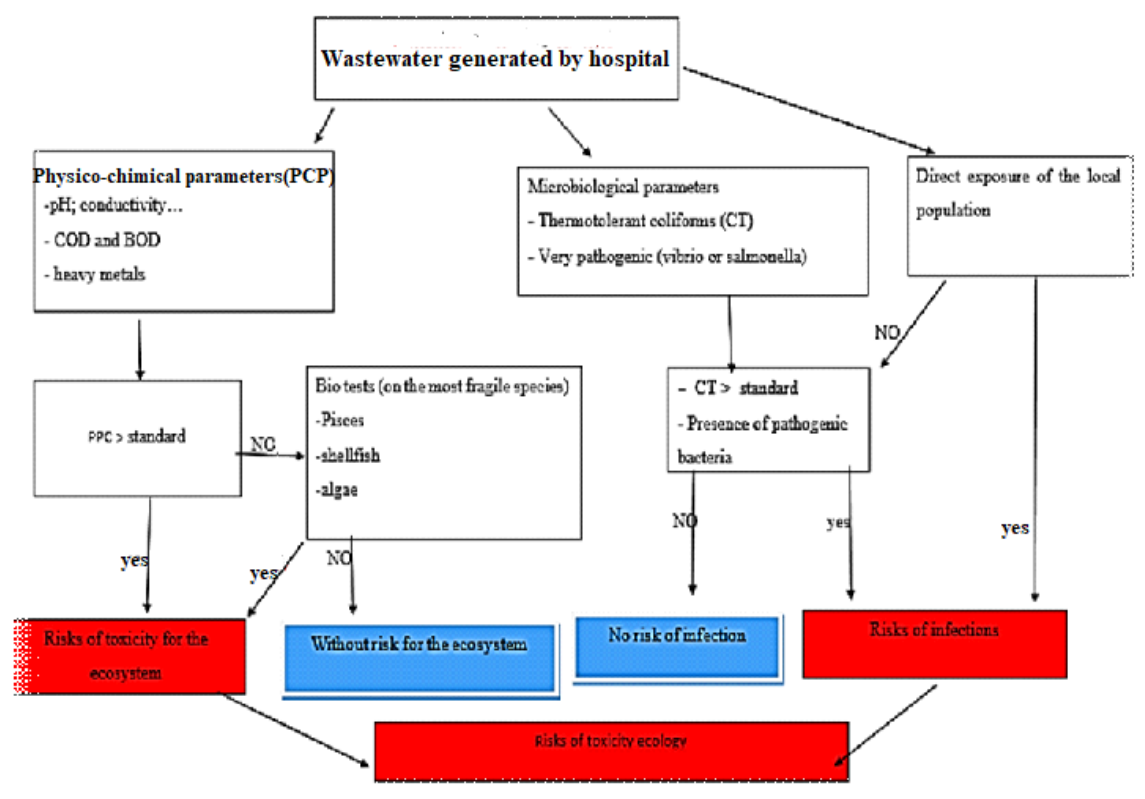

Figure 2: Risks presented by hospital fluids to the ecosystem and the steps for assessing these risks. Source: adapted from Evens et al. [9] 


\section{Difficulties related to the management of hospital wastewaters}

Currently, around the world, very few policies are concerned with the management of hospitals wastewaters [21]. Even noting for the infrastructures which are put in place for the treatment of these effluents before their discharge into the environment [22]. The management techniques usually applied to have enormous limits depending on the parameters involved [23-26]. However, wastewater treatment plants (WWTPs) do not fully remove pharmaceuticals due to a lack of proper design [27-29]. Beyene and Redaie [30] were reported in Ethiopia that the percentage treatment efficiency of the pond at the Hawassa University Referral Hospital varied to 94.11; 87.72; 87.10; 86.52; 68.58; 54.81; 54.59; 31.95; 18.12 and 10.58 for Biological Oxygen Demand $\left(\mathrm{BOD}_{5}\right)$; Sulfide; Total Suspended Solids (TSS); Chemical Oxygen Demand (COD); Nitrate; Nitrite; Total Nitrogen; Total Dissolved Solids; Conductivity and Chloride, respectively. The lack of involvement of authorities in developing countries in sanctions against hospitals polluting the environment with untreated wastewater could be explained by the absence of control structures on the discharge of untreated hospital effluents [31]. Thus, some hospitals ` wastewaters are directly poured into municipal canals which communicate with market gardening areas. The literature shows that the hospitals in these countries do not have qualified staff for wastewaters treatment. As reported by Deblij [23] in Casablanca that 95\% of the staff in charge of the management of hospital effluents in the region of Casablanca Set tat acknowledged that they have not participated in any continuing training addressing the theme of the management of hospital effluents.

\section{Exposure of the population to hospital effluents}

Water is the most used commodity in everyday life. This pressure makes water become increasingly scarce and expensive. In developing countries, poverty and ignorance of health risks make various wastewaters the first choice for watering in vegetable gardens [32]. These practices expose market gardening practitioners to health risks and also lead to the introduction of the various contaminants from these waters into the food chain [33]. However, 800,000 deaths could be avoided per year with good management of these effluents according to the report of the seventy-second World Health Assembly [16]. Indeed, metabolites of degradation residues from products used for health care, and pathogenic germs in aquatic environments largely contribute to the death rates [34-39]. In most African countries, problems regarding both hospital wastewater quantity and quality. Generally, the hospitals have not Wastewater Treatment Plant (WTP) specialized to treat their wastewater. However, the management of these wastewaters bring about some problems on common WTP and environment [35, 40-41]. These problems are due to the pollution of the water by detergents, disinfectants, heavy metals, and the spread of resistance genes [42]. Figure 3 illustrates the communication networks for hospital wastewaters.

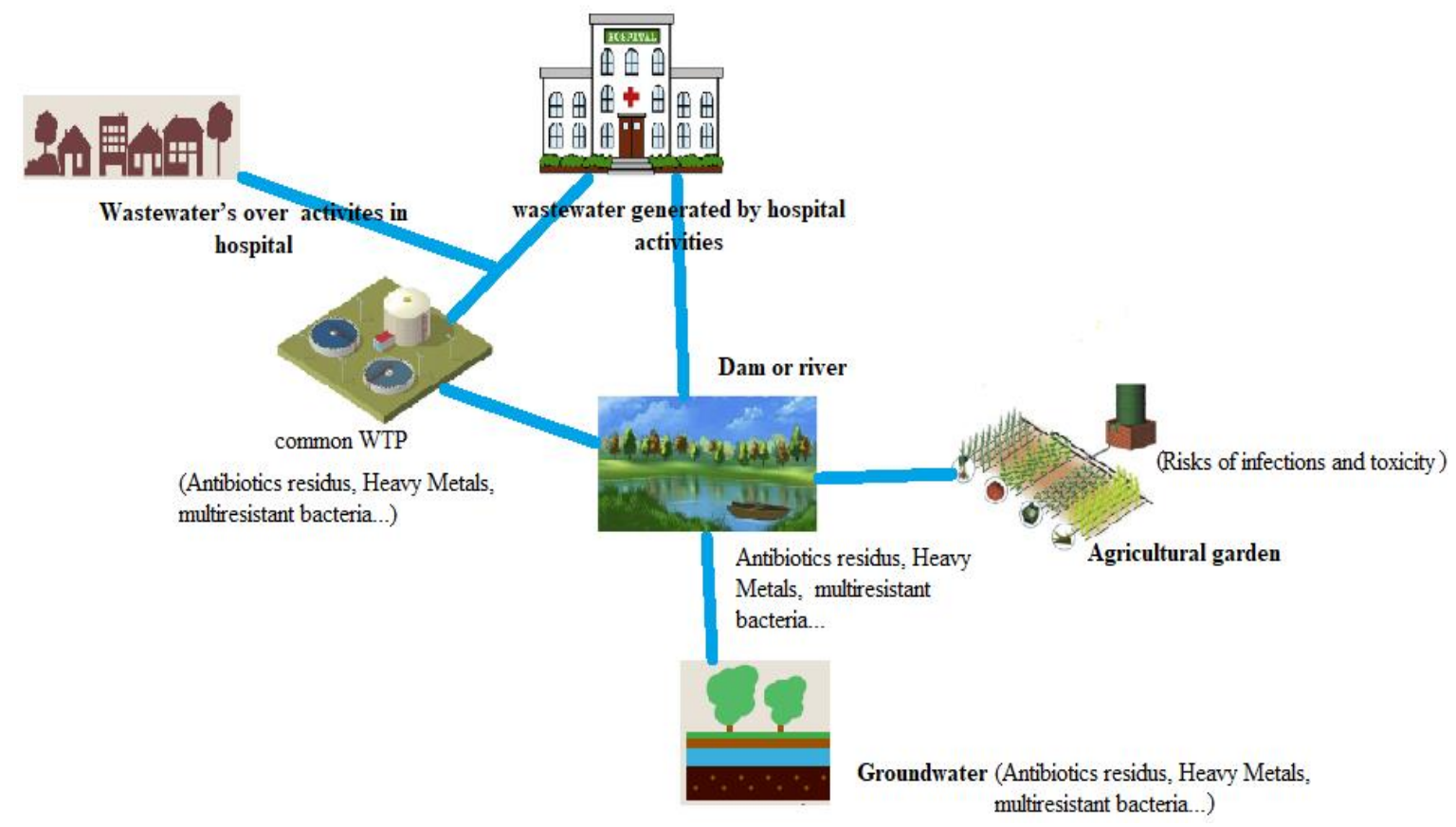

Figure 3. Hospital wastewater problematical and their impact on environment 
In Burkina Faso for example, Somda et al. [43] were brought that hospital wastewaters have been found to contaminate some lettuces and other produces while gardens lands were soiled with some chemical's residues generated by hospital activities. More so, it has been reported in some countries like Benin, Morocco, and Kenya that hospital wastewaters are discharged in common gaps due to inappropriate or faulty flow systems in common WTP $[4-5,40]$. According to World Health Organization (WHO) 2019, 2016, 2011, and 2006, the challenge to improve the quality of freshwater is important because they are remaining one of the leading causes of intoxications or infections among human populations in developing countries.

\section{Risk of toxicity in some hospital wastewaters}

The mismanagement of hospital wastewater creates some problems for the aquatic population owing to the pollutants arising as a result of hospital activities [23; 44-45]. The mains pollutants generated by hospitals are mentioned in Table 1. However, one must note that exposure to some biomedical wastes is a risk factor for infection (up to 100\%), toxicity (about 88\%), eco-toxicity, and cancerogenic [46]. However, only a few actors are interested in monitoring hospital wastewaters parameters, an effort recognized to promote human and environmental health [16].

Table 1. Main pollutants generated by hospitals according to the World Health Organization

\begin{tabular}{ll}
\hline Waste category & Constituents \\
\hline Risk waste & $\begin{array}{l}\text { Infectious waste, pathological waste, sharps, pharmaceutical waste, genotoxic waste, } \\
\text { chemical waste and radioactive waste. }\end{array}$ \\
\hline Non-risk waste Infectious & $\begin{array}{l}\text { Paper and cardboard, packaging, food waste, aerosols and so on. Waste contaminated by any } \\
\text { type of pathogens and includes cultures from laboratory work, waste from surgeries and } \\
\text { autopsies, waste from infected patients, discarded or disposable materials and equipment } \\
\text { which have been in contact with such patients. }\end{array}$ \\
\hline Pathological waste & $\begin{array}{l}\text { Tissues, organs, body parts, fetuses, blood and body fluids. } \\
\text { Include, whether infected or not, needles, syringes, scalpels, infusion sets, saws \& knives, } \\
\text { blades, broken glass and any other item that could cut or puncture. }\end{array}$ \\
\hline Pharmaceutical waste & $\begin{array}{l}\text { Expired or unused pharmaceutical products, surplus drugs, vaccines or sera and discarded } \\
\text { items used in handling pharmaceutical waste such as bottles, boxes, gloves, masks, tubes or } \\
\text { vials. } \\
\text { Cytotoxic drugs and outdated materials, vomitus, feces or urine from patients treated with } \\
\text { cytotoxic drugs or chemicals and materials such as syringes and vials contaminated from } \\
\text { the preparation and administration of such drugs. } \\
\text { Chemicals from diagnostic and experimental work, cleaning processes, housekeeping and } \\
\text { disinfecting procedures, mercury waste such as from broken clinical equipment and spillage } \\
\text { and cadmium waste from discarded batteries. }\end{array}$ \\
\hline Lhemical waste & $\begin{array}{l}\text { Liquid, solid and gaseous waste contaminated with radionuclide generated from in-vitro } \\
\text { analysis of body tissue and fluid, in-vivo body organ imaging and tumor localization, and } \\
\text { investigation and therapeutic procedures. }\end{array}$ \\
\hline Rourtive waste & \\
\hline
\end{tabular}

Source: [47]

\section{Problem of heavy metals in hospital wastewaters}

The hospital wastewaters tend to extend beyond solid waste due to their fluidities. However, they contribute to advance the toxicity of some heavy metals residues [48]. Indeed, in chemicals discharges resulting from hospital activities, heavies' metals remain one of the main forms of dangerous assimilates by the aquatic and human populations [49-50]. The common heavy metals in wastewater treatment are Arsenic, Cadmium, Chromium, Cobalt, Copper, Iron, Lead, Mercury, Silver, and Zinc among others [49]. However, in Nigeria, Eze et al. [49] have brought the presence of some heavy metals in wastewaters and these are detailed in Table 2.

The danger of heavy metal pollutants in water lies in two aspects of their impacts. Firstly, heavy metals have the ability to persist in natural ecosystems for an extended period, and, secondly, they have the ability to accumulate in successive levels of the biological food chain [3, 51-53]. For example, mercury is entering the human body by fish consumption [50,54]. Indeed, mercury is incorporate in body organs in the methyl mercury form. Must note that heavy metals are very carcinogenic [55]. According World Health Organization [47] carcinogenicity is mainly due to heavy metals. However, figure 4 illustrates the sites of action of heavy metals in the human body. 
Table 2. Result of mean concentrations of heavy toxic metals in the hospital wastewater samples

\begin{tabular}{lcccc}
\hline Heavy Toxic Metals & $\begin{array}{c}\text { Sample from } \\
\text { the medical ward (mg/l) }\end{array}$ & $\begin{array}{c}\text { Sample from the new } \\
\text { born baby ward (mg/l) }\end{array}$ & $\begin{array}{c}\text { Sample from the } \\
\text { surgical ward (mg/l) }\end{array}$ & $\begin{array}{c}\text { WHO Limit } \\
(\mathbf{m g} / \mathbf{l})\end{array}$ \\
\hline Arsenic (As) & $0.08 \pm 0.0082$ & $0.06 \pm 0.0163$ & $0.14 \pm 0.0082$ & 0.1 \\
Cadmium (Cd) & $0.13 \pm 0.0163$ & $0.04 \pm 0.0163$ & $0.05 \pm 0.0163$ & 0.1 \\
Lead (Pb) & $0.083 \pm 0.0082$ & $0.02 \pm 0.0082$ & $0.06 \pm 0.0082$ & 0.1 \\
Mercury (Hg) & $0.012 \pm 0.00082$ & $0.007 \pm 0.00163$ & $0.009 \pm 0.0082$ & 0.01 \\
Chromium $\left(\mathrm{Cr}^{+6}\right)$ & $0.09 \pm 0.0163$ & $0.003 \pm 0.00082$ & $0.012 \pm 0.0052$ & 0.01 \\
\hline
\end{tabular}

Source: [49]

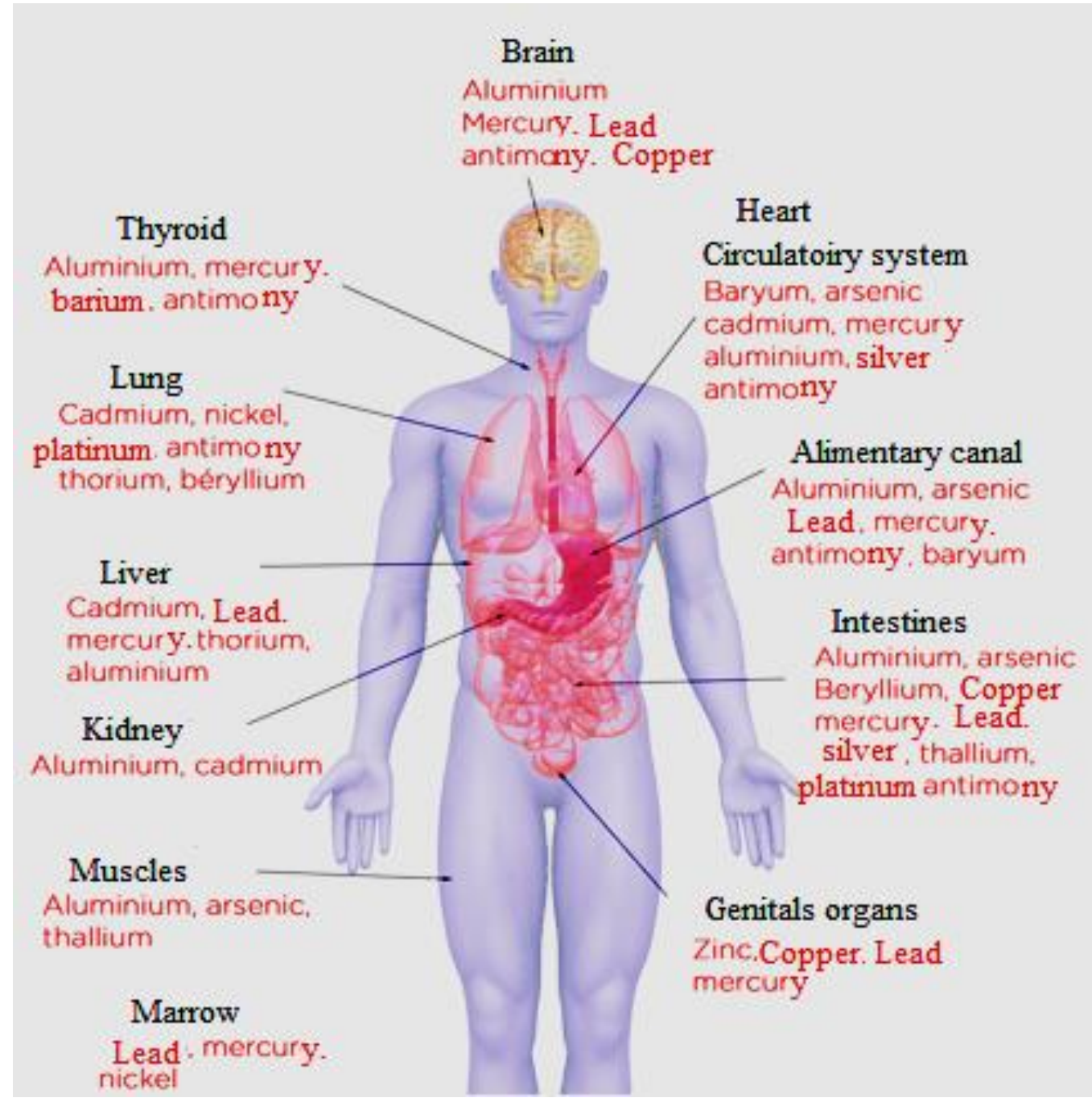

Figure 4: The sites of action of heavy metals in the human body. (Source: adopted from http://oligobordeaux.com/ and translated to English).

\section{COD, BOD and the problem associated with antibiotics in hospital wastewaters}

Chemical Oxygen Demand (COD) and Biological Oxygen Demand (BOD) are some important parameters often used for water quality control. These parameters provide evidence of biological contaminants. In wastewaters with high BOD, the assimilation of organic matters due to microbial activity train hence oxygen consumption. This leads to hypoxic conditions for water bodies with consequent adverse effects on aquatic biota [56]. The high COD may be due to the high concentration of wastes chemically digested which cause also lowering of DO levels in the water. For example, the oil and grease layer of the water bodies influence a lot on $\mathrm{COD}$ and BOD. Indeed, they reduce biological activity in the treatment processes and also cause clogging of pipes in treatment units. However, the environment in most developing African nations is exposed to serious threats due to the higher rates of the COD or BOD from hospital wastewaters than the recommended permissible limits. Thus, in Kenya, K'oreje [40] found that the COD and BOD values ranged from 390 to 3200 mg. $\mathrm{L}^{-1}$ and 213 to $1750 \mathrm{mg} . \mathrm{L}^{-1}$, respectively. Those values of COD and $\mathrm{BOD}_{5}$ concentrations were up to 15 to 25 
times higher than the recommended Kenyan quality standards for effluent discharged into the environment. Elsewhere, Hembach et al. [25] have found the average concentration of $\mathrm{BOD}_{5}$ and $\mathrm{COD}$ to be $45.5 \mathrm{mg}$. $\mathrm{L}^{-1}$ and $185.5 \mathrm{mg} . \mathrm{L}^{-1}$, respectively, while the concentration reported in Nigeria was BOD5 $<25 \mathrm{mg} . \mathrm{L}^{-1}$ and $\mathrm{COD}<90 \mathrm{mg}$. $\mathrm{L}^{-1}$. In addition to the challenges associated with $\mathrm{COD}$ and BOD, special attention is needed on antibiotic residues in hospital wastewater that promote the emergence and circulation of resistance genes [57-58].

\section{Emergence of bacterial resistance to antibiotics}

Bacteria resistance to antibiotics has continued to present as a serious challenge since the 1940s [59-60]. This antibiotic resistance is expressed by several mechanisms, including modification of the targets of antibiotics, the expulsion of antibiotic residues through membrane channels, and the production of inhibitory enzymes (beta-lactams) of antibiotics. Bacterial resistance to antibiotics has been established over time as shown in Figure 5 for the advent of beta-lactamases [60]. They have been described extensively among bacteria of human origin and are now of great concern in hospital wastewaters.

\section{Bacterial resistance to antibiotics in hospital wastewaters}

The major microorganisms found in wastewaters are viruses, bacteria, fungi, protozoa, and helminths. Microbial pollutants can also serve as indicators of water quality. Untreated effluents generated by hospital activities can contribute significantly to the spread of microbial pollutants mainly as multi-resistant bacteria (MRB) from patient's pathological products in the environment $[2,61-62]$. Indeed, the diversity and huge consumption of antibiotics used in humans' therapies eventually of bacterial infection end up in the wastewaters [63-65]. The chronic release of antibiotic residues collected in the hospital sewer systems and the environmental conditions are favorable for selection bacterial resistance and transfer of antibiotic-resistance genes (ARGs) among various bacterial species [34, 64]. Indeed, in ARGs, many are easily transmitted between bacteria via horizontal transfer [56; 65-67]. Eventually, the bacterial resistance to antibiotics is also increasing in hospital and non-hospital wastewater. For example, Moges et al. [68] was brought in Ethiopia that the situation of gram-positive bacterial resistance in hospital and non-hospital environments were found to be 53/68 (81.5\%) and 26/48 (54.2\%), respectively [68].

Distributions of the multiple drug resistance genes among gram-positive bacteria have become a major issue. Indeed, the transfer of multiple drug resistance genes among this group of bacteria is mainly due to the dissemination of genes like mecA or mecC. The distribution of these genes is a significant problem in both developed and developing countries $[2 ; 69 ; 70 ; 71]$. However, poor management of hospital wastewater represents a means to disseminate the resistance genes. Moreover in Brazil, Zagui et al. [69] were brought that the resistance of gram-negative bacteria in hospital and urban wastewater is very worrying. Table 3 present the details of theirs results. As in the case of the gram-positive bacteria, hospital wastewater contributes to the dissemination of gram-negative bacteria presenting a worse case of multiple drug resistance where the incriminated genes produce substances inhibiting beta-lactam action (ESBLs). Must note that these genes can be transferred to other bacteria sensitive to beta-lactam [72]. However, it has been established in Africa and elsewhere that these antibiotic-resistant genes affecting animal and human health have been recovered from the environmental specimen [23, 43, 73-74]. In addition to the genes encoding ESBLs, the carbapenemases have been described in hospital effluents by several investigators [65, 70, 75]. Thus, in hospital wastewaters from Slovenia and Australia, Urška et al. [76] were described several types of genes encoding for ESBLs and carbapenemases as shown in Table 4.

The acquisition of resistance genes is promoted in hospital effluents by the circulation of mobile genetic carriers. Figure 6 shows the different mechanisms for transferring and acquiring genes through these media. These problems evoke around hospital wastewaters render vulnerable the riverine and users of dams and gutters or the common WTP system [3, 43, 77]. Must note it is estimated that antibiotic-resistant bacteria cause 23,000 and 25,000 deaths in the United States and Europe, respectively [78]. This situation is similar worldwide and even worse in low- and middle-income countries where a high infectious disease burden is coupled with the rapid emergence and spread of microbial drug resistance [66].

\section{Heavy metal residues and antibiotic resistance in hospital liquid effluents}

The evolution and dissemination of antibiotic resistance genes are likely triggered by anthropogenic pollutants [79-80]. Hospital wastewaters are one of the primary factors in the proliferation of resistance genes [26, 81-82]. Already being a liquid, they flow over large areas. In addition, their physicochemical parameters 
(following pollutants brought in by various hospital activities) favor the selection of the most resistant bacteria. However, several investigations have shown correlations of heavy metal pollution, antibiotic-resistant genes, and mobile genetic carriers of resistance genes [83-86]. Indeed, complex transposons are mobile supports favoring the cointegration of genes for resistance to heavy metals and antibiotics as shown in figure 6 . Thus, Yuyi et al. [80] have shown (Figure 7) correlations between heavy metal pollution in Wuhan lakes and the frequency of resistance genes characterized in bacteria isolated from these lakes.

Table 3. Resistance rate of gram-negative isolates to commonly used antibiotics

\begin{tabular}{|c|c|c|c|c|}
\hline Species & $\begin{array}{l}\text { Sampling } \\
\text { point }\end{array}$ & Antibiotic resistance profile & $\begin{array}{l}\text { Resistance } \\
\text { phenotype }\end{array}$ & bla genes \\
\hline \multirow{18}{*}{ K. pneumoniae } & 3 & AMO, AMC, ATM, CPM, CTX, CFO, CAZ, ERT, IPM, MER, STX & MDR & KPC, TEM \\
\hline & 2 & AMO, AMC, ATM, CPM, CTX, CFO, CIP, ERT, IPM, STX & MDR & KPC, CTX-M-8, SHV, TEM \\
\hline & 3 & AMO, AMC, ATM, CPM, CTX, CFO, CAZ, ERT, IPM, MER & MDR & KPC, SHV \\
\hline & 2 & AMO, AMC, ATM, CPM, CTX, CFO, CAZ, ERT, IPM, MER & MDR & CTX-M-1, SHV, TEM \\
\hline & 3 & AMO, AMC, ATM, CPM, CTX, CFO, CAZ, STX, TET & MDR & TEM \\
\hline & 3 & AMO, AMC, ATM, CPM, CTX, CAZ, ERT, IPM, MER & MDR & $\mathrm{KPC}$ \\
\hline & 2 & AMO, AMC, ATM, CFO, ERT, IPM, MER, STX & MDR & - \\
\hline & 3 & AMO, AMC, ATM, CPM, CTX, CFO, STX & MDR & TEM \\
\hline & 2 & AMO, AMC, ATM, CTX, GEN, STX & MDR & SHV, TEM \\
\hline & 3 & AMO, AMC, ATM, CTX, ERT & MDR & $\mathrm{KPC}$ \\
\hline & 3 & ATM, CPM, CTX, CFO & MDR & TEM \\
\hline & 2 & AMO, AMC & - & $\mathrm{KPC}$ \\
\hline & 1 & AMO & - & - \\
\hline & 2 & AMO & - & - \\
\hline & 4 & AMO & - & - \\
\hline & 4 & AMO & - & - \\
\hline & 4 & AMO & - & - \\
\hline & 5 & AMO & - & - \\
\hline \multirow{10}{*}{ P. aeruginosa } & 1 & ATM, CFO & - & - \\
\hline & 3 & $\mathrm{ATM}, \mathrm{CFO}$ & - & - \\
\hline & 1 & CFO & - & - \\
\hline & 2 & CFO & - & - \\
\hline & 3 & CFO & - & $\mathrm{KPC}$ \\
\hline & 2 & CFO & - & - \\
\hline & 5 & ATM & - & - \\
\hline & 3 & ATM & - & - \\
\hline & 1 & - & - & -- \\
\hline & 2 & - & - & - \\
\hline
\end{tabular}




\begin{tabular}{|c|c|c|c|c|}
\hline & 2 & AMO, AMC, AMP, ATM, CPM, CTX, CFO, CAZ, CLO, STX, TET & MDR & - \\
\hline \multirow[t]{2}{*}{ E. coli } & 1 & AMO, AMP, CTX & - & CTX-M-8 \\
\hline & 1 & TET & - & - \\
\hline \multirow{2}{*}{ S. liquefaciens } & 2 & AMO, AMC, AMP, ATM, CPM, CTX, CFO, CAZ, ERT, IPM, MER & MDR & $\mathrm{KPC}$ \\
\hline & 4 & AMO, AMC, AMP, CFO & - & - \\
\hline \multirow{2}{*}{ K. oxytoca } & 1 & AMO, AMC, CAZ, STX, TET & MDR & - \\
\hline & 1 & AMO, ATM, CAZ & - & - \\
\hline \multirow{2}{*}{ R. ornithinolytica } & 4 & AMO, AMC, AMP, CFO & - & - \\
\hline & 1 & AMO, AMP, CAZ & - & - \\
\hline H. alvei & 2 & AMO, ATM, CTX, CAZ, CLO, GEN, STX & MDR & CTX-M-1, SHV, TEM \\
\hline E. cloacae & 5 & AMO, ATM, CTX, CAZ & - & SHV \\
\hline C. amalonaticus & 4 & AMO, AMP & - & - \\
\hline S. fonticola & 2 & AMO, AMP & - & - \\
\hline P. rettgeri & 5 & AMO & - & - \\
\hline K. ozaenae & 1 & AMO & - & - \\
\hline A. baumannii & 5 & - & - & - \\
\hline C. koseri & 1 & - & - & - \\
\hline
\end{tabular}

Table 4. Encoded $\beta$-lactamases in isolated bacteria from general hospital Ptuj, Laßnitzhöhe rehabilitation clinic and Leech surgery clinic wastewaters

\begin{tabular}{|c|c|c|c|c|c|c|c|c|}
\hline \multirow{2}{*}{$\begin{array}{l}\text { Time of } \\
\text { sampling }\end{array}$} & \multirow{2}{*}{$\begin{array}{l}\text { Sample } \\
\text { number }\end{array}$} & \multirow{2}{*}{$\begin{array}{l}\text { Selective } \\
\text { chromogenic } \\
\text { media }\end{array}$} & \multirow{2}{*}{ Species identification } & \multicolumn{5}{|c|}{ Antibiotic resistant gene (ARG) Time } \\
\hline & & & & VIM & KPC & NDM & CTXM & OXA48 \\
\hline \multicolumn{9}{|l|}{ GH Ptuj } \\
\hline \multirow{4}{*}{ July 2017} & 1 & CARB Ec & Citrobacter freundii & VIM & NEG & NEG & CTXM9 & NEG \\
\hline & 4 & CARB KESC & Enterobacter kobei & VIM & NEG & NEG & NEG & NEG \\
\hline & 5 & ESBL KESC & Enterobacter kobei & VIM & NEG & NEG & NEG & NEG \\
\hline & 14 & ESBL KESC & Enterococcus faecium & NEG & NEG & NEG & CTXM9 & NEG \\
\hline \multirow{10}{*}{ July 2018} & 1 & ESBL Ec & Escherichia coli & NEG & NEG & NEG & CTXM1 & NEG \\
\hline & 2 & ESBL Ec & Escherichia coli & NEG & NEG & NEG & CTXMı & NEG \\
\hline & 3 & ESBL Ec & Citrobacter freundii & NEG & NEG & NEG & CTXM9 & NEG \\
\hline & 4 & ESBL Ec & Escherichia coli & NEG & NEG & NEG & CTXM1 & NEG \\
\hline & 5 & ESBL Ec & Citrobacter freundii & NEG & NEG & NEG & СTXMı & NEG \\
\hline & 8 & ESBL KESC & Klebsiella pneumoniae & VIM & NEG & NEG & СTXMı & NEG \\
\hline & 11 & CARB Ec & Klebsiella oxytoca & VIM & NEG & NEG & NEG & NEG \\
\hline & 13 & CARB Ec & Citrobacter freundii & VIM & NEG & NEG & CTXMı & NEG \\
\hline & 16 & CARB KESC & Klebsiella oxytoca & VIM & NEG & NEG & NEG & NEG \\
\hline & 17 & CARB KESC & Klebsiella oxytoca & VIM & NEG & NEG & NEG & NEG \\
\hline
\end{tabular}

Citation: Ouedraogo GA, Kone S, Ouedraogo A, Ouedraogo HS, Traore R, Cisse H, Bassolé IHN, Traore Y and Savadogo A. Ecotoxicity of hospital wastewaters and their impact on bacterial multi-drug resistance: a review. J Life Sci Biomed, 2021; 11(4): 58-71. DOI: https://dx.doi.org/10.51145/jlsb.2021.8 


\begin{tabular}{|c|c|c|c|c|c|c|c|c|}
\hline & 18 & CARB KESC & Klebsiella oxytoca & VIM & NEG & NEG & NEG & NEG \\
\hline & 19 & CARB KESC & Klebsiella oxytoca & VIM & NEG & NEG & NEG & NEG \\
\hline & 20 & CARB KESC & Klebsiella oxytoca & VIM & NEG & NEG & NEG & NEG \\
\hline & 25 & OXA KESC & Pseudomonas mosselii & NEG & NEG & NEG & CTXM1 & OXA48 \\
\hline \multicolumn{9}{|c|}{ PK Laßnitzhöhe } \\
\hline \multirow{4}{*}{ July 2017} & 22 & OXA KESC & $\begin{array}{l}\text { Citrobacter } \\
\text { amalonaticus }\end{array}$ & NEG & NEG & NEG & NEG & OXA48 \\
\hline & 23 & OXA P & Citrobacter freundii & NEG & NEG & NEG & NEG & OXA48 \\
\hline & 24 & ESBL Ec & Escherichia coli & NEG & NEG & NEG & CTXM9 & NEG \\
\hline & 25 & ESBL Ec & Escherichia coli & NEG & NEG & NEG & CTXM9 & NEG \\
\hline \multirow{7}{*}{ July 2018} & 24 & OXA Ec & Citrobacter freundii & NEG & NEG & NEG & NEG & OXA48 \\
\hline & 25 & OXA Ec & Citrobacter freundii & NEG & NEG & NEG & NEG & OXA48 \\
\hline & 26 & OXA Ec & Citrobacter freundii & NEG & NEG & NEG & NEG & OXA48 \\
\hline & 27 & OXA Ec & Citrobacter freundii & NEG & NEG & NEG & NEG & OXA48 \\
\hline & 28 & OXA KESC & Klebsiella oxytoca & NEG & NEG & NEG & NEG & OXA48 \\
\hline & 29 & OXA KESC & Klebsiella oxytoca & NEG & NEG & NEG & NEG & OXA48 \\
\hline & 30 & OXA KESC & $\begin{array}{l}\text { Citrobacter } \\
\text { amalonaticus }\end{array}$ & NEG & NEG & NEG & NEG & OXA48 \\
\hline \multicolumn{9}{|l|}{ PK Leech } \\
\hline \multirow{2}{*}{ July 2017} & 32 & ESBL Ec & Escherichia coli & NEG & NEG & NEG & CTXMı & NEG \\
\hline & 33 & ESBL Ec & Bacillus subtilis & NEG & NEG & NEG & CTXMı & NEG \\
\hline \multirow{5}{*}{ July 2018} & 1 & ESBL Ec & Escherichia coli & NEG & NEG & NEG & CTXMı & NEG \\
\hline & 2 & ESBL Ec & Escherichia coli & NEG & NEG & NEG & CTXM1 & NEG \\
\hline & 3 & ESBL Ec & Escherichia coli & NEG & NEG & NEG & CTXMı & NEG \\
\hline & 4 & ESBL Ec & Escherichia coli & NEG & NEG & NEG & CTXMı & NEG \\
\hline & 5 & ESBL Ec & Escherichia coli & NEG & NEG & NEG & СТXMı & NEG \\
\hline
\end{tabular}

Source: [76]

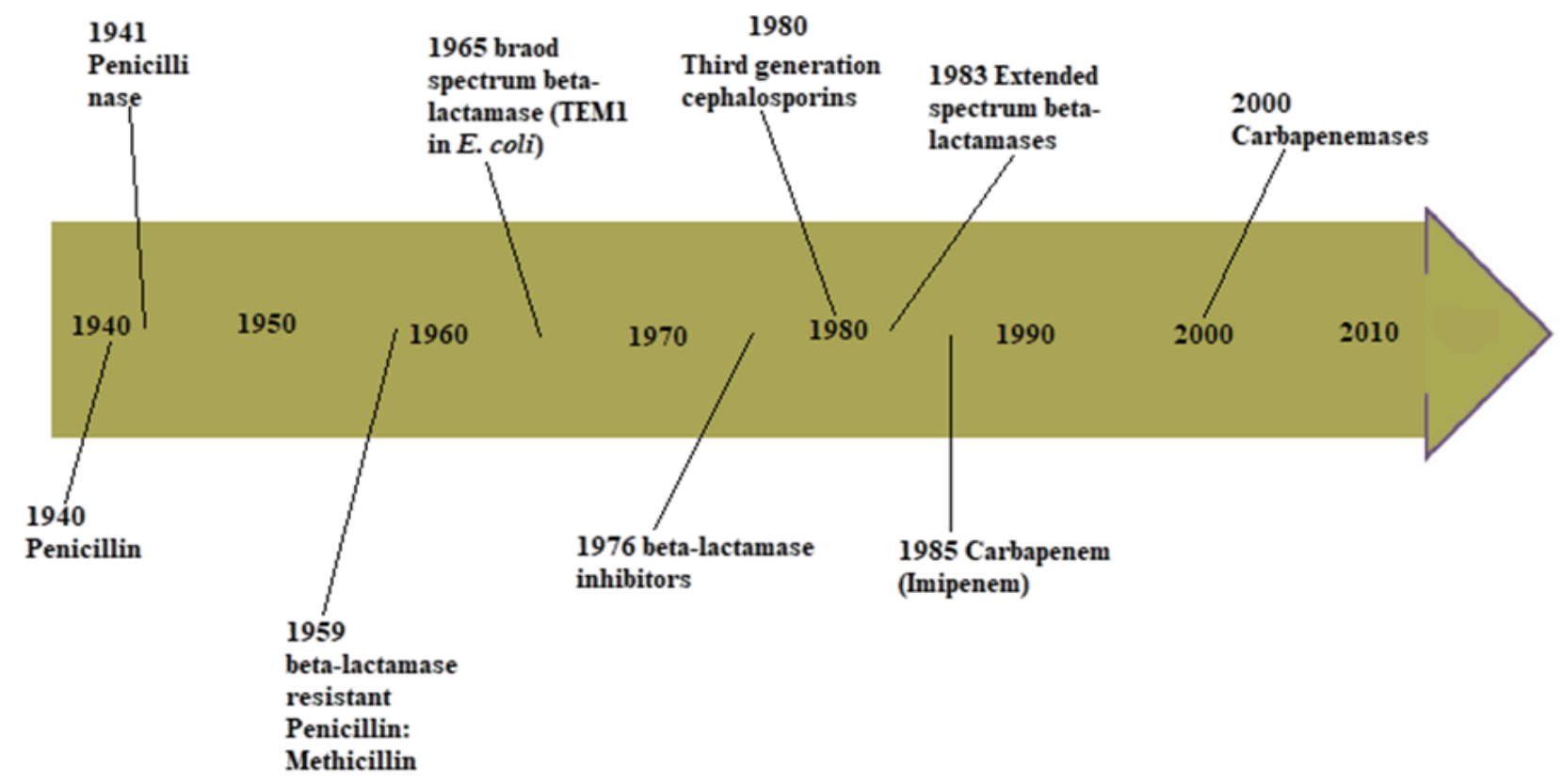

Figure 5. The evaluation of the beta lactamase enzyme. Source: [62]

Citation: Ouedraogo GA, Kone S, Ouedraogo A, Ouedraogo HS, Traore R, Cisse H, Bassolé IHN, Traore Y and Savadogo A. Ecotoxicity of hospital wastewaters and their impact on bacterial multi-drug resistance: a review. J Life Sci Biomed, 2021; 11(4): 58-71. DOI: https://dx.doi.org/10.51145/jlsb.2021.8 

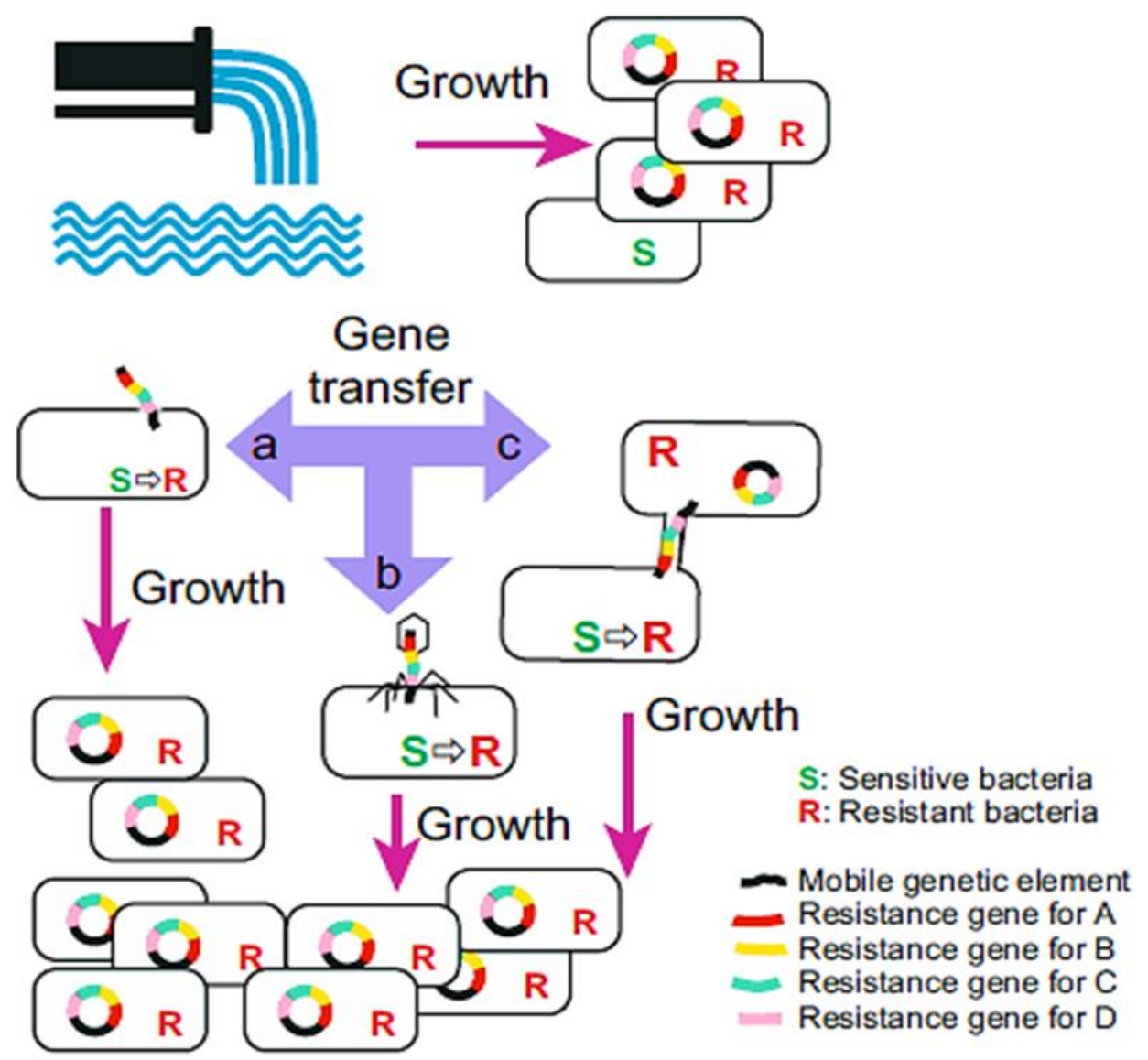

Figure 6. Mechanism of resistance genes transfer from a multidrug-resistant strain (R) to a susceptible bacteria (S). Source: [65]

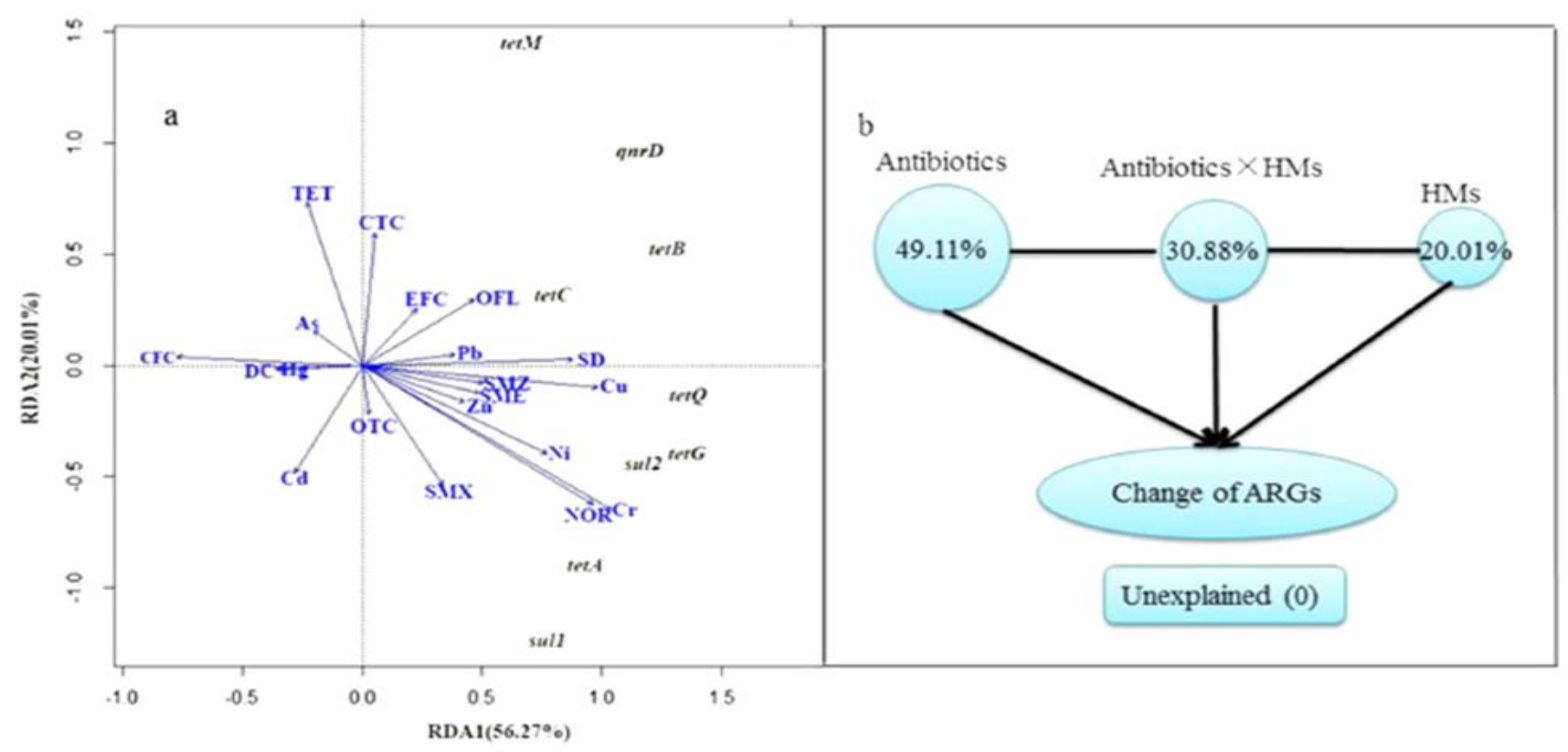

Figure 7. Correlation of resistance of bacteria to antibiotics and heavy metals. Source: [80]

\section{CONCLUSION}

In light of this review, the management of hospital sewages effluents is not a top priority for most authorities around the world. It is more neglected or even abandoned in developing countries. Scarce investigations are carried out with regard to hospital liquid effluents. However, the high loads of organic matter, chemical matter, 
heavy metals, and multi-resistant bacteria in hospital sewage effluents, and poor management of effluents present risks and threats to aquatic biodiversity, treatment stations, and other peri-urban agricultural areas from these effluents, risk of infection, and intoxication from the at-risk populations who use them. Elsewhere, the presence of antibiotic and heavy metal residues contributes to bacterial selection on one hand and the emergence of bacterial resistance genes on the other.

\section{DECLARATIONS}

\section{Authors' Contributions}

G.A.Ouedraogo wrote the original draft of the manuscript. G.A.Ouedraogo, S.Kone, A.Ouedraogo, H.S.Ouedraogo, R.Traore and H.Cisse organized the data, helped in writing and review of the manuscript. I.H.N.Bassolé, Y.Traore and A.Savadogo supervised the study and validated the review of the manuscript. All authors have read and approved the final version.

\section{Acknowledgements}

This work was supported by Laboratory of Applied Biochemistry and Immunology and Laboratory of Epidemiology and Surveillance of Foodborne Diseases of University Joseph Ki-ZERBO.

\section{Competing interests}

The authors declare that they have no competing interests.

\section{REFERENCES}

1. Damià B, Božo Ž, Antoni G. Journal of Environmental Chemical Engineering Toxicity tests in wastewater and drinking water treatment processes: A complementary assessment tool to be on your radar. Journal of Environmental Chemical Engineering. 2020; 8(104262). https://doi.org/10.1016/j.jece.2020.104262

2. Dhafer MMAS, Georgette NN, Amandine L, Jean-Paul O, Crispin M, John P. Ecotoxicology and Environmental Safety Hospital wastewaters: A reservoir and source of clinically relevant bacteria and antibiotic resistant genes dissemination in urban river under tropical conditions. Ecotoxicology and Environmental Safety. 2020; 200(February), 9. https://doi.org/10.1016/j.ecoenv.2020.110767

3. Nyamukamba P, Makwena JM, Nikita T, Ikechukwu PE. Evaluating Physicochemical Parameters, Heavy Metals, and Antibiotics in the Influents and Final Effluents of South African Wastewater Treatment Plants. Polish Journal of Environmental Studies. 2019; 28(3), 1305-1312. https://doi.org/10.15244/pjoes/85122

4. Elias A, Kanhounnon SA, Gbèdodé W, Boni CC, Dogbè CA, Koumolou L, Bonou B, Fiogbe ED, Aléodjrodo PE. Physicochemical and microbiological characterization of effluents from the "Centre Hospitalier Universitaire de la Mère et d e l'Enfant Lagune (CHU-MEL)" discharged in the Cotonou lagoon in Benin. International Journal of Biological and Chemical Sciences 2018; 12(1991-8631), $1955-1964$. http://indexmedicus.afro.who.int\%OAPhysicochemical

5. Asmaa QLM, Said B. M. Application d'une méthode d'étude quantitative et qualitative des rejets liquides hospitaliers au niveau de la Région de Marrakech Tensift El Haouz, Maroc. European Scientific Journal. 2016 ; 12(32), $110-130$. https://doi.org/10.19044/esj.2016.v12n32p110

6. Lutterbeck AC, Colares GS, Dell'Osbel N, Da Silva PF, Lourdes TK, Machado EL, Hospital laundry wastewaters: A review on treatment alternatives, life cycle assessment and prognosis scenarios. Journal of Cleaner Production. 2020; 273(122851). https://doi.org/10.1016/j.jclepro.2020.122851

7. Bisognin RP, Wolff DB, Carissimi E, Prestes OD, Zanella R, Storck TR, Clasen B. Potential environmental toxicity of sewage effluent with pharmaceuticals. Ecotoxicology (Springer). 2020. https://doi.org/10.1007/s10646-020-02264-7

8. Alam M, Imran M, Ahmad SS. Screening of Metal and Antibiotic Resistance in Beta-lactamase Producing Coliform Bacteria from Hospital Wastewater of Northern India. Recent Patents on Biotechnology. 2020; 14, 63-77. https://doi.org/10.2174/1872208313666191002130406

9. Evens E, Perrodin Y, Keck G, Blanchard JM, Vermande P. Effects of hospital wastewater on aquatic ecosystem. ResearchGate, October. 2002. https://www.researchgate.net/publication/232724983

10. Kosma IC, Kapsi MG, Konstas PSG, Trantopoulos EP, Boti VI, Konstantinou IK, Albanis AT. Assessment of multiclass pharmaceutical active compounds (PhACs) in hospital WWTP influent and effluent samples by UHPLC-Orbitrap MS: Temporal variation, removals and environmental risk assessment. Environmental Research. 2020; 191(August), 110152. https://doi.org/10.1016/j.envres.2020.110152

11. Alexander J, Hembach N, Schwartz T. Evaluation of antibiotic resistance dissemination by wastewater treatment plant effluents with different catchment areas in Germany. Scientific Reports. 2020; 10(1), 1-9. https://doi.org/10.1038/s41598-020-65635-4

12. Ojemaye MO, Adefisoye MA, Okoh AI. Nanotechnology as a viable alternative for the removal of antimicrobial resistance determinants from discharged municipal effluents and associated watersheds: A review. Journal of Environmental Management. 2020; 275(May), 111234. https://doi.org/10.1016/j.jenvman.2020.111234

13. Fiorentino A, Estebanb B, Garrido-Cardenas JA, Kowalska K, Rizzoa L, Aguerac A, Sánchez PJA. Effect of solar photo-Fenton process in raceway pond reactors at neutral $\mathrm{pH}$ on antibiotic resistance determinants in secondary treated urban wastewater. Journal of Hazardous Materials. 2019; 378(April), 120737. https://doi.org/10.1016/j.jhazmat.2019.06.014

14. Iakovides IC, Michael-Kordatou BI, Moreira NFF, Ribeiro AR, Fernandes T, Pereira MFR, Nunes OC, Manaia CM, Silva AMT, FattaKassinos D. Continuous ozonation of urban wastewater: Removal of antibiotics, antibiotic-resistant Escherichia coli and antibiotic resistance genes and phytotoxicity. Water Research. 2019; 159، 333-347. https://doi.org/10.1016/j.watres.2019.05.025 
15. Yves L. Contamination des eaux par les résidus de médicaments et stratégies de prévention. Dossier (Environnement et Santé). 2020 ; 6(N 594), 18-23. https://doi.org/10.1016/j.actpha.2020.01.007

16. Organisation Mondiale de la Santé (OMS). Projet de stratégie mondiale OMS sur la santé, l'environnement et les changements climatiques: la transformation nécessaire pour améliorer durablement la vie et le bien-être grâce à des environnements sains. Soixante-douzième assemblée mondiale de la santé Point 11.6 de l'ordre Du Jour Provisoire, 18 avril. $2019 ; 19(A 72 / 15), 1-27$. https://apps.who.int/iris/bitstream/handle/10665/328611/A72 15-fr.pdf

17. OMS/FAO/OIE. Suivi mondial des progrès des pays dans la lutte contre la résistance aux antimicrobiens (RAM). 2018 ; pp. 7. https://doi.org/http://www.who.int/antimicrobial-resistance/global-action-plan/database/en

18. Bavo DW, Langenhove HV, Demeestere K, Saerens K, Wispelaere DP, Dewulf J. Chemosphere Ciprofloxacin ozonation in hospital wastewater treatment plant effluent: Effect of $\mathrm{pH}$ and $\mathrm{H}_{2} \mathrm{O}_{2}$. Chemosphere. 2010; 78(9), 1142-1147. https://doi.org/10.1016/j.chemosphere.2009.12.026

19. Parameswari E, Lakshmanan A, Thilagavathi T. Chromate Resistance and Reduction by Bacterial Isolates. Australian Journal of Basic $\begin{array}{lllll}\text { and } \quad \text { Applied } & \text { Sciences. 2009; 3(2), }\end{array}$ https://www.researchgate.net/profile/Parameswari E/publication/228371283 Chromate Resistance and Reduction by Bacterial Is olates/links/5cdaae53458515712ea97943/Chromate-Resistance-and-Reduction-by-Bacterial-Isolates.pdf

20. Yan S, Zhang XL, Tyagi RD, Drogui P. Guidelines for hospital wastewater discharge. Current Developments in Biotechnology and Bioengineering. 2020; BV. https://doi.org/10.1016/B978-0-12-819722-6.00016-X

21. Rashmi S, Thakur IS. Cancer treatment drugs and endocrine-disrupting chemicals release and fate in hospital wastewater. In Current Developments in Biotechnology and Bioengineering. 2020; BV. https://doi.org/10.1016/B978-0-12-819722-6.00007-9

22. Yadav YB, Pandey AK, Kumar LR, Kaur R, Yellapu SK, Balasubramanian S, Tyagi RD, Drogui P. microbiology: special emphasis on hospital wastewater. In Current Developments in Biotechnology and Bioengineering. 2020; BV. https://doi.org/10.1016/B978-0-12819722-6.00001-8

23. Deblij S, Bouchaib B, Boutaleb NEAS. Diagnostic de la Gestion des Effluens Liquides Hospitaliers de la Region de Casablanca-Settat Diagnosis of the Management of Hospital Liquids Discharges in the Region of Casablanca-Settat. European Scientific Journal. 2019; 15(6), 171-190. https://doi.org/10.19044/esj.2019.v15n6p171

24. Stange C, Sidhu JPS, Toze S, Tiehm A. International Journal of Hygiene and Comparative removal of antibiotic resistance genes during chlorination, ozonation, and UV treatment. International Journal of Hygiene and Environmental Health. 2019; 222(3), 541-548. https://doi.org/10.1016/j.ijheh.2019.02.002

25. Hembach N, Alexander J, Hiller C, Wieland A, Schwartz T. Dissemination prevention of antibiotic resistant and facultative pathogenic bacteria by ultrafiltration and ozone treatment at an urban wastewater treatment plant. Scientific Reports, June. 2019 ; 1-12. https://doi.org/10.1038/s41598-019-49263-1

26. Kûmmerer K. and Henninger A. Promoting resistance by the emission of antibiotics from hospitals and households into effluent. Clin Microbiol Infec. 2003; 12(9), 1203-214. https://doi.org/10.1111/j.1469-0691.2003.00739.x

27. Michael SG, Michael-Kordatou I, Nahim-Granados S, Polo-López MI, Rocha J, Martínez-Piernase AB, Fernández-Ibáñezc P, Agüerae A, Manaia CM, Fatta-Kassinos D. Investigating the impact of UV-C / $\mathrm{H}_{2} \mathrm{O} 2$ and sunlight / $\mathrm{H}_{2} \mathrm{O}_{2}$ on the removal of antibiotics, antibiotic resistance determinants and toxicity present in urban wastewater. Chemical Engineering Journal. 2020; 388 , 124383. https://doi.org/10.1016/j.cej.2020.124383

28. Khan NA, Khan SU, Ahmed S, Farooqi IH, Yousefi M, Mohammadi AA, Changani F. Recent Trends in Disposal and Treatment Technologies of. Trends in Analytical Chemistry. 2019; 115744. https://doi.org/10.1016/j.trac.2019.115744

29. Rajbongshi S, Shah YD, Sajib AU. Pharmaceutical waste management: A review. European Journal of Biomedical and Pharmaceutical Sciences. 2016 $3(12)$ $192-206$. https://www.researchgate.net/profile/Yamini_Shah2/publication/318440497_Pharmaceutical_waste_management_a_review/links/59 69d57aa6fdcc18ea74c6fl/pharmaceutical-waste-management-a-review.pdf

30. Beyene H, Redaie G. Assessment of Waste Stabilization Ponds for the Treatment of Hospital Wastewater: The Case of Hawassa University Referral Hospital. World Applied Sciences Journal. 2011; 15(1), 142-150. https://www.researchgate.net/profile/GetachewRedae/publication/278882875_Assessment_of_Waste_Stabilization_Ponds_for_the_T reatment_of_Hospital_Wastewater_The_Case_of_Hawassa_University_Referral_Hospital/links/5587b35408aef58c03a04cbe/Assess ment-of-Waste-Stabilization-Ponds-for-the-Treatment-of-Hospital-Wastewater-The-Case-of-Hawassa-University-ReferralHospital.pdf

31. Wanduma KZ, Kaboka AK. Cliniques universitaires de kinshasa en RDC [biological and chemical characterization of liquid waste of university of clinical kinshasa (DRC)]. International Journal of Innovation and Applied Studies. 2016; 18(2), 9324. https://search.proquest.com/openview/c80a49441c6b92990bodb286dc8ad819/1?pq-origsite=gscholar\&cbl=2031961

32. Kapepula L, NdikumanaT, Dieu-Donné M, Alconero PL, Tamungang NEB, Tarimo I, Bruggen BVD. Qualitative and quantitative analysis of the pollutant load of effluents discharged Northwestern of Lake Tanganyika, in the Democratic Republic of Congo. African Journal of Environmental Science and Technology. 2020; 14(November), 361-373. https://doi.org/10.5897/AJEST2020.2903

33. Dubois-Brissonnet F, Guillier L. Les maladies microbiennes d'origine alimentaire. Cahiers de Nutrition et de Dietetique. 2020 ; 55(1), 30-38. https://doi.org/10.1016/j.cnd.2019.12.001

34. Ebomah KE, Okoh AI. An African perspective on the prevalence, fate and effects of carbapenem resistance genes in hospital ef fluents and wastewater treatment plant (WWTP) final effluents: A critical review. Heliyon. 2020; 6(February), 3899. https://doi.org/10.1016/j.heliyon.2020.e03899.

35. Ugwu AC, Ignatius NE, Ogolodom MP, Maduka BU, Akhigbe RO, Mbaba AN, Egbeyemi OO. Hepatotoxicity of radiographic fixer effluent on wistar rats. International Research Journal of Public and Environmental Health. 2019; 6(July), 53-58. https://doi.org/https://doi.org/10.15739/irjpeh.19.007

36. Ekwanzala MD, Dewar JB, Ilunga Kamika I, Momba MNB. Tracking the environmental dissemination of carbapenem-resistant Klebsiella pneumoniae using whole genome sequencing. Science of the Total Environment. 2019; 691, 80-92. https://doi.org/10.1016/j.scitotenv.2019.06.533

37. Sims N, Kasprzyk-Hordern B. Future perspectives of wastewater-based epidemiology: Monitoring infectious disease spread and resistance to the community level. Environment International. 2020; 139(March), 105689. https://doi.org/10.1016/j.envint.2020.105689 
38. Cardenas MAR, Imtiaj A, Foon YL, Dawes L, Their R, Rajapakse J. Removal of micropollutants through a biological wastewater treatment plant in a subtropical climate, Queensland-Australia. Journal of Environmental Health Science and Engineering. 2016; 14, 110. https://doi.org/10.1186/s40201-016-0257-8

39. Nikolaou A, Meric S, Despo F. Occurrence patterns of pharmaceuticals in water and wastewater environments. Analytical and Bioanalytical Chemistry. 2007; 387(4), 1225-1234. https://doi.org/10.1007/s00216-006-1035-8

40. K'oreje KOLD, Vergeynst D, Ombaka P, De Wispelaere M, Okoth $\mathrm{CH}$, Langenhove KV. Chemosphere Occurrence patterns of pharmaceutical residues in wastewater, surface water and groundwater of Nairobi and Kisumu city, Kenya. Elsevier (Chemosphere). 2016; 149(238-244), 7. https://doi.org/10.1016/j.chemosphere.2016.01.095

41. Guessennd N, Ouattara MB, Ouattara ND, Nevry RK, Gbonon V, Tiekoura K, Dosso M. Étude des bactéries multirésistantes des effluents hospitaliers d'un centre hospitalier et universitaire (CHU) de la ville d 'Abidjan (Côte d 'Ivoire). Journal of Applied Biosciences. 2013 ; 69(1997-5902), 5456-5464. https://doi.org/10.4314/jab.v69io.95071

42. Ekwanzala MD, Lehutso FR, Kasonga TK, Dewar JB, Momba MNB. Environmental Dissemination of Selected Antibiotics from Hospital Wastewater to the Aquatic. Antibiotics. 2020; 9(431), 1-16. https://doi.org/doi:10.3390/antibiotics9070431

43. Somda NS, Bonkoungou OJI, Traoré O, Bassolé IHN, Traoré Y, Barro N, Savadogo A. Serotyping and antimicrobial drug resistance of salmonella isolated from. African Journal of Infectious Diseases. 2017; 11(2), 24-30. https://doi.org/doi.org/10.21010/ajid.v1li2.4

44. Rani R, Singh S. Green chemistry and its applications in hospital wastewater and its treatment. In Research and Applications (Vol. ooo). Elsevier Inc. 2021 https://doi.org/10.1016/B978-0-12-817742-6.00009-8

45. Koopaei NN, Abdollahi M. Health risks associated with the pharmaceuticals in wastewater. DARU Journal of Pharmaceutical Sciences. 2017; 25(9), 1-7. https://doi.org/10.1186/s40199-017-0176-y

46. Aissi KA, Edorh AP, Pognon E, Barogui Y, Hounkpatin A, Tchiakpe E, Loko F. Gestion des effluents liquides biomedicaux et risques sanitaires associés dans la zone sanitaire d'Abomey-Calavi/So-Ava au Sud du Benin. In Conférence Internationale : 7ème édition des Journées Scientifiques 2iE Ougadougou, du ler au 5 avril 2013 ; (pp. 572 (304-309)).

47. World Health Organization (WHO). The review on antimicrobial resistance, tackling drug-resistant infections globally: Final report and recommendations AMR review. 2017; $2016 \quad$ May 25 . https://books.google.bf/books?hl=fr\&lr=\&id=MnOyDwAAQBAJ\&oi=fnd\&pg=PP4\&dq=World+Health+Organization+(WHO,+2017), +the+ number+of+new+cases+is+expected+to+rise+by+\%E2\% $88 \%$ BC70\%25\&ots=agQ1IkIth\&sig=YVDaayl2NHs5loRCD8gBwO2oeao\&redir_esc $=\mathrm{y} \# \mathrm{v}=$ onepage\& $\mathrm{q} \& \mathrm{f}=$ false

48. Laffite A, Kilunga PI, Kayembe JM, Devarajan N, Mulaji CK, Giuliani G, Slaveykova VI, Poté J. Hospital effluents are one of several sources of metal, antibiotic resistance genes, and bacterial markers disseminated in sub-Saharan urban rivers. Frontiers in Microbiology. 2016; 7(JUL), 1-14. https://doi.org/10.3389/fmicb.2016.01128

49. Eze CT, Onwurah INE. Environmental health risk assessment of hospital wastewater in enugu urban, Nigeria. CEST. 2015; 7(Proceedings of the 14th International Conference on Environmental Science and Technology; Rhodes, Greece), pp.238. https://cest2015.gnest.org/papers/cest2015_00238_poster_paper.pdf

50. Himri ME, Himri AE. Analytical evaluation for the determination of mercury in water. Annales Toxicologie Analytiques. 2012; 24(3), 153-158. https://doi.org/10.1051/ata/2012019

51. Liu C, Liu Y, Feng C, Wang P, Lanping Y, Liu D, Sun S, Fangkun Wang. Chemosphere Distribution characteristics and potential risks of heavy metals and antimicrobial resistant Escherichia coli in dairy farm wastewater in. Chemosphere. $2021 ; 262$, 127768. https://doi.org/10.1016/j.chemosphere.2020.127768

52. Djibrine AO, Guira F, Abdelsalam T, Nodjimadji R, Madjimbaye P, Tarnagda B, Abdoullahi HO, Traoré Y, Savadogo A. (2O18). Risks Assessments of Heavy Metals Bioaccumulation in Water and Tilapia nilotica Fish from Maguite Island of Fitri Lake. Current Journal of Applied Science and Technology. 2018; 26(2), 1-9. https://doi.org/10.9734/CJAST/2018/39384

53. Kouamé MK, Biego GHM, Ake-assi Y, N'Zi GA. Estimation de l' apport en mercure à partir de la consommation de poisson en Côte d 'Ivoire. Sciences \& Nature. 2007; 4(N²), 171-177. DOI: https://doi.org/10.4314/scinat. v4i2.42141

54. Ikenaka LA, Thompson Y, Yohannes YB, Ito T, Ichise G, Sam N, Bortey WJJ, Van VV. Human Health Risk from Consumption of Marine Fish Contaminated with DDT and Its Metabolites in Maputo Bay, Mozambique. Bulletin of Environmental Contamination and Toxicology, 2018; O(0), 0. https://doi.org/10.1007/s00128-018-2323-7

55. Nitika S, Sodhi KK, Kumar M, Singh DK. Heavy Metals eco-toxicity with major concern to Chromium and recent advancement in remediation technologies. Environmental Nanotechnology. 2020; Monitoring \&\#x0026; Management, S2215-1532(30370-6), 100388. https://doi.org/10.1016/j.enmm.2020.100388

56. Pazda M, Rybicka M, Stolte S, Bielawski KP, Stepnowski P, Kumirsk J, Wolecki D, Mulkiewicz E. Identification of Selected Antibiotic Resistance Genes in Two Different Wastewater Treatment Plant Systems in Poland: A Preliminary Study. Molecules (MDPI). 2020; 25(2851), 1-18. https://doi.org/doi:10.3390/molecules25122851

57. Khan NA, Sirajuddin A, Izharul HF, Imran A, Vambol V, Fazlollah CE, Mahmood Y, Sergij V, Khan SU, Khan UA. Trends in Analytical Chemistry Occurrence, sources and conventional treatment techniques for various antibiotics present in hospital wastewaters: A critical review. Trends in Analytical Chemistry. 2020; 129. https://doi.org/10.1016/j.trac.2020.115921

58. Abdel-Mohsein HS, Feng M, Fukuda Y, Tada C. Remarkable Removal of Antibiotic-Resistant Bacteria During Dairy Wastewater Treatment Using Hybrid Full-scale Constructed Wetland. Water, Air and Soil Pollution. 2020 ; 231 :397. https://doi.org/https://doi.org/10.1007/s11270-020-04775-9

59. Rehman K, Pervaiz W, Victor F, Ateeq B, Akash MSH. Antibiotics' presence; presence in hospitals and associated wastes. In Antibiotics and Antimicrobial Resistance Genes in the Environment. Elsevier Inc. 2020; https://doi.org/10.1016/B978-0-12-818882-8.00003-6

6o. Paulshus E. Antibiotic resistance in wastewater. Norwegian University of Life Sciences. 2020 ; pp. 156 https://nmbu.brage.unit.no/nmbu-xmlui/handle/11250/2663905

61. Jyothirmai VK, Sharmila SMR, Arun S. Degradation of ciprofloxacin using fenton process and its effect on biodegradability. Rasayan Journal Chemistry, 2020; 13(4), 2274-2280. http://dx.doi.org/10.31788/RJC.2020.1346074

62. Radhakrishna L, Nagarajan P. Isolation and Preliminary Characterization of Bacterial from Liquid Hospital Wastes. International Journal of PharmTech Research. 2015; 308-314. https://www.researchgate.net/profile/Prabhu_Nagarajan4/publication/281687768_Isolation_and_preliminary_characterization_of_ba cterial_from_liquid_hospital_wastes/links/5694a5da08aeab58a9a2fa27/Isolation-and-preliminary-characterization-of-bacterial-fromliquid-hospital-wastes.pdf 
63. Organisation mondiale de la Santé (OMS). Programmes pour le bon usage des antimicrobiens dans les établissements de santé dans les pays à revenu intermédiaire, tranche inférieure. Une boîte à outils pratique de l'OMS [Antimicrobial stewardship programmes in health-care facilities in low- and mid. 2020; pp. 88. ISBN 978-92-4-000307-1 (version électronique) https://doi.org/http://apps.who.int/iris.

64. Shao S, Wu X. Critical Reviews in Biotechnology Microbial degradation of tetracycline in the aquatic environment: a review. Critical Reviews in Biotechnology, 2020; O(0), 1-9. https://doi.org/10.1080/07388551.2020.1805585

65. Karkman A, Thuy Do T, Walsh F, Marko VMPJ. Antibiotic-Resistance Genes in Waste Water. Trends in Microbiology. 2018; 26(3), 220228. https://doi.org/10.1016/j.tim.2017.09.005

66. Bougnom BP, Piddock LJV. Wastewater for Urban Agriculture: A Significant Factor in Dissemination of Antibiotic Resistance. Environmental Science \& Technology. 2017; 51, 5863-5864. https://doi.org/10.1021/acs.est.7bo1852

67. Mei-Ting G, Qing-Bin Y, Yang J. Distinguishing Effects of Ultraviolet Exposure and Chlorination on the Horizontal Transfer of Antibiotic Resistance Genes in Municipal Wastewater. Environmental Science \& Technology. $2015 ; 8$. https://doi.org/10.1021/acs.est.5bo0644

68. Moges F, Endris M, Belyhun Y, Worku W. Isolation and characterization of multiple drug resistance bacterial pathogens from waste water in hospital and non-hospital environments, Northwest Ethiopia. BMC Research Notes. 2014; 7(1), 1-6. https://doi.org/10.1186/1756-0500-7-215

69. Zagui GS, De Andrade NL, Moreira NC, Silva TV, Machado GP, Costa DAL, Segura-Muñoz SI. Gram-negative bacteria carrying $\beta$ lactamase encoding genes in hospital and urban wastewater in Brazil. Environmental Monitoring Assessment. 2020 ; 192 :376. https://doi.org/https://doi.org/10.1007/s10661-020-08319-w

70. Rania AA, Nsreen MK, Rasha HE, Mona MA. Evaluation for the Novel mecC Methicillin Resistance among Methicillin Resistant Staphylococcal Isolates in two Egyptian University Hospitals. IMedPub Journals. 2017; 9(1:71), 1-5. https://doi.org/10.4172/19898436.100071

71. Milheiriço C, De Lencastre H, Tomasz A. MRSA strains carrying the novel mecC gene: full genome sequencing identifies in the genetic background several determinants that modulate the resistant phenotype. American Society for Microbiology. 2017 ; AACO2500-16, 26. https://doi.org/10.1128/AAC.02500-16

72. Adegoke AA, Fatunla OK, Anthony I, Okoh AI. Critical threat associated with carbapenem- resistant gram-negative bacteria: prioritizing water matrices in addressing total antibiotic resistance. Annals of Microbiology. 2020; $70(43)$. https://doi.org/https://doi.org/10.1186/s13213-020-01579-4

73. Neil W, Wareham DW, Guerra B, Teale C. Carbapenemase-producing Enterobacteriaceae and non-Enterobacteriaceae from animals and the environment: an emerging public health risk of our own making? Journal of Antimicrobial Chemotherapy. 2014; 69, $287-291$. https://doi.org/10.1093/jac/dkt392

74. Fernando B, Martinez JL, Canton R. Antibiotics and antibiotic resistance in water environments. Elsevier (Current Opinion in Biotechnology). 2008; 19, 260-265. https://doi.org/10.1016/j.copbio.2008.05.00

75. Hocquet D, Muller A, Bertrand X. What happens in hospitals does not stay in hospitals: antibiotic-resistant bacteria in hospital wastewater systems. Journal of Hospital Infection. 2016; 16(195-6701). https://doi.org/10.1016/j.jhin.2016.01.010

76. Urška R, Duh D, Cimerman M, Šostar TS. Uncorrected Proof resistant bacteria Uncorrected Proof. Journal of Water, Sanitation and Hygiene for Development. 2020; 8, 1-8. https://doi.org/10.2166/washdev.2020.086

77. Nitiema LW, Savadogo B, Zongo D, Kabore A, Poda JN, Traoré AS, Dianou D. Microbial Quality of Wastewater Used in Urban Truck Farming and Health Risks Issues in Developing Countries: Case Study of Ouagadougou in Burkina Faso. Journal of Environmental Protection. 2013; 4, 575-584. https://doi.org/10.4236/jep.2013.46067

78. World Health Organization (WHO). Résistance Aux Antimicrobiens: Rapport Mondial Sur La Surveillance. 2011: https://apps.who.int/iris/bitstream/handle/10665/123394/RC60 Resolutions 2013 R1 15144 FR.pdf?sequence=3

79. Cai L, Wang Z, Sun J, Yao F, Qiaoxin Z, Yumeng Y, Qindong X, Shiwei W, Xiaoyan J. Antimicrobial Resistance Genes and Bacteria Detected in Hospital Sewage May Provide Valuable Information in Clinical Antimicrobial Resistance. Research Sqaure. $2020 ; 1-16$. DOI: https://doi.org/10.21203/rs.3.rs-93424/v1

80. Yuyi Y, Chen X, Xinhua C, Hui L, Wang J. Antibiotic resistance genes in surface water of eutrophic urban lakes are related to heavy metals, antibiotics, lake morphology and anthropic impact. Ecotoxicology. 2017; 26(6), 831-840. https://doi.org/10.1007/s10646-0171814-3

81. Triggiano T, Calia C, Diella G, Montagna MT, De Giglio O, Caggiano G. The Role of Urban Wastewater in the Environmental Transmission of Antimicrobial Resistance: The Current Situation in Italy (2010-2019). Microorganisms. 2020 https://doi.org/doi:10.3390/microorganisms8101567

82. Li J, Cheng W, Xu L, Strong PJ, Chen H. Antibiotic-resistant genes and antibiotic-resistant bacteria in the effluent of urban residential areas, hospitals, and a municipal wastewater treatment plant system. Environment Science and Pollution Research. 2015; 10(22), 45874596. https://doi.org/10.1007/s11356-014-3665-2

83. Ting G, Lou C, Zhai W, Xianjin T, Hashmi ZM, Murtaza R, Li Y, Xingmei L, Jianming Xu. Science of the Total Environment Increased occurrence of heavy metals, antibiotics and resistance genes in surface soil after long-term application of manure. Science of the Total Environment. 2018; 635, 995-1003. https://doi.org/10.1016/j.scitotenv.2018.04.194

84. Di Cesare A, Eckert EM, D'Urso S, Bertoni R, Gillan DC, Wattiez R, Corno G. Co-occurrence of integrase 1, antibiotic and heavy metal resistance genes in municipal wastewater treatment plants. Water Research. 2016; 94, 208-214. https://doi.org/10.1016/j.watres.2016.02.049.

85. Xiuling J, Qunhui S, Liu F, Jing M, Gang X, Yuanlong W, Minghong W. Antibiotic resistance gene abundances associated with antibiotics and heavy metals in animal manures and agricultural soils adjacent to feedlots in Shanghai; China. Journal of Hazardous Materials. 2012; 235-236, 178-185. https://doi.org/10.1016/j.jhazmat.2012.07.040

86. Jolibois B, Guerbet M, Vassal S. Glutaraldehyde in hospital wastewater. Archives of Environmental Contamination and Toxicology. 2002; 42(2), 137-144. https://doi.org/10.1007/s00244-001-0011-8 